\title{
Pengaruh Ragi Tape terhadap pH, Bakteri Asam Laktat dan Laktosa Yogurt
}

\author{
Effect of Yeast on pH, Lactate Bacteria, and Lactose of Yogurt
}

\author{
Asti Yosela Oktaviana, Dadang Suherman, dan Endang Sulistyowati \\ Jurusan Peternakan, Fakultas Pertanian, Universitas Bengkulu \\ Jalan W.R Supratman Kandang Limun Bengkulu 38371A \\ Email : astiyosela@yahoo.com
}

\begin{abstract}
The objective of this research was to evaluate chemical properties, such as $\mathrm{pH}$, lactic acid bacteria, and lactose levels in yogurt fermented with yeast or yogurt fermented with lactic acid. This research was conducted in November through December 2014 at Gapoktan Sumber Mulya Desa Suka Sari, Kabupaten Kepahiang Provinsi Bengkulu. Experimental design applied in this study was completely randomized design with 3 treatments and 4 replications. P1 = addition of 3\% (of 1000 gram milk) plain yogurt starter as control; P2 = substitution of plain yogurt starter with $25 \%$ yeast ; P3 = substitution of plain yogurt starter with $50 \%$ yeast. Results showed that addition of $25 \%$ and $50 \%$ of yeast did not affect significantly on chemical properties; $\mathrm{pH} 3.9-4.5$, lactate

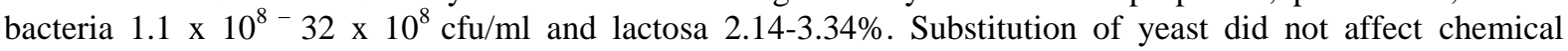
properties of yogurt.
\end{abstract}

Key words : chemical properties, yeast, yogurt.

\begin{abstract}
ABSTRAK
Tujuan penelitian ini adalah mengevaluasi sifat kimia, seperti $\mathrm{pH}$, kandungan bakteri asam laktat, dan kadar laktosa dalam yogurt yang difermentasi dengan ragi tape atau yogurt yang difermentasi dengan asam laktat. Penelitian ini dilaksanakan pada bulan November sampai Desember 2014 di Gapoktan Sumber Mulya Desa Suka Sari, Kabupaten Kepahiang Provinsi Bengkulu. Desain penelitian yang digunakan adalah rancangan acak lengkap (RAL) dengan 3 perlakuan dan 4 ulangan. P1 = penambahan 3\% (per 1000 gram susu) plain yogurt starter sebagai kontrol; P2 = penggantian plain yogurt starter dengan $25 \%$ ragi ; P3 = penggantian plain yogurt starter dengan 50\% ragi. Hasil menunjukkan bahwa penggantian $25 \%$ dan $50 \%$ ragi tidak mempengaruhi secara signifikan sifat kimia; $\mathrm{pH} 3.9-4.5$, bakteri asam laktat $1.1 \times 10^{8-} 32$ x $10^{8} \mathrm{cfu} / \mathrm{ml}$ dan laktosa 2.14-3.34\%. Substitusi ragi tidak mempengaruhi sifat kimia yogurt.
\end{abstract}

Kata kunci : sifat kimia, ragi, yogurt.

\section{PENDAHULUAN}

Susu merupakan bahan pangan yang memiliki kandungan protein, lemak, laktosa, mineral dan vitamin yang dapat membantu memenuhi kebutuhan manusia (Widodo, 2003). Selain itu mengkonsumsi susu segar secara rutin akan sangat membantu dalam kesehatan tubuh manusia karena kandungan nutrisi yang terkandung masih bersifat alami. Namun susu segar mudah rusak oleh mikroorganisme karena merupakan media pertumbuhan yang baik bagi bakteri patogen. Untuk mengatasi kerusakan dari susu tersebut perlu dilakukan pengolahan dan pengawetan. Pengolahan dan pengawetan dapat dilakukan melalui fermentasi susu menjadi yogurt. Fermentasi susu menjadi yogurt terdapat lima bakteri yang dapat digunakan, yaitu Lactobacillus acidophilus, Bifidobacterium bifidum, Lactobacillus thermophilus, dan Lactobacillus bulgaricus. Streptococcus thermophilus 
dan Lactobacillus bulgaricus merupakan bakteri yang biasa digunakan untuk pembuatan yogurt yang menguraikan laktosa (gula susu) menjadi asam laktat dan berbagai komponen aroma dan citarasa (Widodo, 2002).

Yogurt merupakan hasil fermentasi susu dengan bantuan bakteri asam laktat (BAL) terhadap susu yang telah dipasteurisasi (Surajudin et al., 2006). Yogurt mempunyai cita rasa asam, cita rasa asam yang dihasilkan dari fermentasi bakteri Lactobacillus bulgaricus dan Streptococcus thermophillus. Kualitas yang baik dihasilkan ketika perbandingan Lactobacilli dan Streptococci pada produk akhir adalah $1: 1$ (Overby, 1988).

Lactobacillus bulgaricus berperan dalam pembentukan aroma, sedangkan Streptococcus thermophilus berperan dalam pembentukan cita rasa khas yogurt. Bakteri mempunyai kebutuhan nutrisi yang komplek, termasuk di dalamnya ketersediaan untuk memfermentasi beberapa jenis gula termasuk laktosa. Lactobacillus bulgaricus dan Streptococcus thermophilus menghasilkan asam laktat yang menggumpalkan susu menjadi yogurt dan merupakan sumber dari manfaat yogurt. Bakteri paling banyak terdapat pada susu tergolong ke dalam Lactobacillaceae dan Streptococaceae. Disamping itu, Escherichia coli sering dijumpai tetapi organisme ini tidak dikehendak dan berapa kehadirannya berhubungan langsung dengan kondisi kebersihan produk susu (Volk dan Wheeler, 1990). Komposisi yogurt secara kimia protein $4-6 \%$, lemak $0,1-1 \%$, laktosa
2-3\%, asam laktat $0,6-1,3 \%, \mathrm{pH} 3,8-4,6 \%$ (Susilorini dan Sawitri, 2007). Berbeda dengan pendapat Surajudin et al. ( 2006), yang menyebutkan bahwa yogurt memiliki kandungan lemak dalam empat golongan, yaitu yogurt kadar lemak tinggi (4,5-10\%), kadar lemak sedang (3-4\%), kadar lemak rendah (1-3\%), dan yogurt kadar lemak sangat rendah (kurang dari 1\%). Kandungan protein 3,4 gram pada yogurt yang mengandung lemak tinggi dan 1,6 gram pada yogurt yang mengandung lemak rendah.

Ragi tape merupakan populasi campuran yang terdiri dari spesies-spesies genus Aspergilius, Saccharomyces, Candida, Hansenulla, dan bakteri Acetobacter (Dwijoseputro, 1988). Ragi tape digunakan untuk pembuatan produk fermentasi seperti misal tape ketan dan tape singkong. Ragi tape berasal dari tepung beras yang dicampurkan dengan bahan-bahan lain sehingga dapat membantu dalam proses fermentasi. Di dalam ragi ini terdapat mikroorganisme yang dapat mengubah karbohidrat (pati) menjadi gula sederhana (glukosa) yang selanjutnya diubah lagi menjadi. Karbohidrat (pati) terfermentasi maka menghasilkan sejumlah besar asam laktat yang akan menurunkan nilai $\mathrm{pH}$ sehingga menimbulkan rasa asam pada yogurtnya. Berdasarkan SNI 01-2981-1992 (DSN, 1992), syarat mutu jumlah asam yogurt adalah $0,5-2,0 \% \mathrm{~b} / \mathrm{b}$.

Umumnya yogurt dibuat hanya menggunakan starter bakteri Lactobacilus bulgaricus dan Streptococcus thermophilus, seperti ditunjukkan pada 
hasil temuan Prasetyo (2010), bahwa penggunaan starter yogurt dengan level $3 \%, 5 \%, 7 \%$ tidak berpengaruh terhadap $\mathrm{pH}$, kadar asam laktat dan kadar laktosa. Lain halnya dengan Suriasih (2011), menghasilkan penemuan yogurt dengan penambahan cairan tape ketan yang menunjukkan bahwa cairan tape ketan berpengaruh terhadap $\mathrm{pH}$, kadar laktosa dan glukosa.

Efryantoni (2011), menyebutkan dalam temuannya bahwa peningkatan konsentrasi starter dengan menggunakan bakteri Lactobacillus bulgaricus level 5\%, $10 \%$ dan $15 \%$ dapat meningkatkan produksi asam laktat sebesar 0,24-0,47 persen, namun tidak memberikan pengaruh terhadap $\mathrm{pH}$ yogurt, $\mathrm{pH}$ yang dihasilkan dalam yogurt berkisar antara 5,53 - 5,83 dan bersifat sangat asam. Berdasarkan hal tersebut, maka untuk mengetahui perbedaan sifat kimia yogurt perlu dilakukan penelitian pembuatan yogurt dengan penambahan langsung ragi tape tanpa adanya fermentasi tape terlebih dahulu. Uji kadar laktosa, uji pH dan uji kadar asam laktat dapat digunakan untuk melihat kualitas yogurt tersebut.

Penelitian ini bertujuan untuk mengetahui sifat kimia seperti kadar asam laktat, kadar laktosa yogurt hasil fermentasi dengan ragi tape dan yogurt hasil fermentasi bakteri asam laktat. Penambahan ragi tape dalam pembuatan yogurt diduga dapat berpengaruh terhadap sifat kimia yogurt.

\section{METODE PENELITIAN}

\section{Waktu dan Tempat}

Penelitian ini dilaksanakan dari bulan November - Desember 2014 di Gapoktan Sumber Mulya Desa Suka Sari, Kabupaten Kepahiang Provinsi Bengkulu.

\section{Alat dan Bahan}

Alat yang digunakan dalam penelitian ini antara lain gelas erlenmeyer, gelas ukur, panci, timbangan analitik, termometer suhu, sendok atau spatula, lemari es, kotak steril, $\mathrm{pH}$ meter, kompor, waterbath dan show case. Bahan yang digunakan susu sapi murni dari GAPOKTAN Sumber Mulya Desa Suka Sari, Kabupaten Kepahiang Provinsi Bengkulu, starter bakteri asam laktat (BAL) yaitu Lactobacillus bulgaricus dan Streptococcus thermophillus, ragi tape halus.

\section{Tahapan Penelitian}

Susu dipasteurisasi pada suhu 61$63^{\circ} \mathrm{C}$ selama 30 menit, kemudian suhu diturunkan hingga mencapai $43^{\circ} \mathrm{C}$. Setiap perlakuan menggunakan masing-masing 1000 gram susu yang telah dipasteurisasi, ditambahkan starter sesuai perlakuan $(0 \%$, $25 \%, 50 \%$ ) dan ragi tape halus sesuai perlakuan $(25 \%$ dan $50 \%)$ kemudian diaduk hingga rata. Susu yang telah ditambahkan starter dimasukkan kedalam gelas atau botol dan ditutup hingga rapat, diinkubasi selama 4 jam, setelah itu dilanjutkan dengan proses penyimpanan untuk menghambat proses fermentasi yang lebih lanjut selama 12 jam. 


\section{Rancangan Penelitian}

Rancangan penelitian yang digunakan dalam penelitian ini adalah Rancangan Acak Lengkap (RAL). Dalam penelitian ini dilakukan tiga perlakuan dan setiap perlakuan diulang sebanyak empat kali.

$$
Y_{i j}=\mu+T_{i}+\epsilon_{i j}
$$

$\mathbf{Y}_{\mathbf{i j}}=$ Respon pengamatan individu yang

memperoleh perlakuan ke-i

Ulangan ke-j

$\boldsymbol{\mu} \quad=$ Nilai tengah

$\mathbf{T}_{\mathbf{i}} \quad=$ Pengaruh perlakuan ke-i

$\epsilon_{\mathrm{ij}} \quad=$ Sisaan

\section{Kombinasi Perlakuan}

$\mathbf{P 1}=$ Penambahan 3\% (dari volume susu murni 1000 gram) starter plain yogurt sebagai kontrol.

$\mathbf{P 2}=$ Penggantian starter plain yogurt dengan $25 \%$ ragi tape.

P3 = Penggantian starter plain yogurt dengan $50 \%$ ragi tape.

\section{Analisis Data}

Data hasil penelitian akan dianalisis dengan ANOVA dan jika menunjukkan berbeda nyata maka akan diuji dengan Duncan's Multiple Range Test (DMRT) (Yitnosumarto, 1993).

\section{Variabel yang diamati}

\section{Uji pH}

Dilakukan dengan menggunakan $\mathrm{pH}$ meter, diatur dengan larutan buffer sampai nilai 7 , kemudian mencelupkan $\mathrm{pH}$ meter ke dalam sampel sehingga terbaca nilai pHnya (Hadiwiyoto, 1983).

\section{Uji Kadar Asam Laktat}

Nilai keasaman dihitung dengan metode Mann's acid Test (Hadiwiyoto, 1983). Sampel dimasukkan ke erlenmeyer sebanyak $10 \mathrm{ml}$ ditambahkan lima tetes indikator fenolftalin $1 \%$ kemudian dititrasi mengunakan larutan $\mathrm{NaOH} 0,1 \mathrm{~N}$ sampai berwarna pink. Jumlah larutan $\mathrm{NaOH} \quad 0,1 \quad \mathrm{~N}$ yang dibutuhkan untuk mentitrasi sample dicatat.

$\%$ Keasaman $=\frac{\text { mlNaOH } \times 0,009}{\text { volumesampel }} \times 100 \%$

\section{Uji Kadar Laktosa}

Timbang 2-5 gram yogurt kedalam Erlenmeyer $300 \mathrm{ml}$, tambah $30 \mathrm{ml}$ air dan panaskan sampai mendidih sampai 10 menit. Angkat Erlenmeyer sampai suhunya menurun. Dalam keadaan hangat, dimasukkan 1 gram ragi roti. Sumbat erlemenyer dengan kapas dan simpan pada tempat yang hangat selama 48 jam. Panaskan erlenmeyer dan didihkan larutan selama 10 menit guna mematikan mikroorganisme dan enzim, kemudian dinginkan. Masukkan larutan kedalam labu $100 \mathrm{ml}$ dan tepatkan sampai tanda garis dengan air suling, kocok dan saring. Pipet $10 \mathrm{ml}$ saringan dan masukkan kedalam erlenmeyer $500 \mathrm{ml}$. tambahkan $500 \mathrm{ml}$ air suling dan $25 \mathrm{ml}$ larutan luff (dengan pipet/serta beberapa butir batu didih). Hubungkan erlenmeyer dengan pendingin tegak dan penangas listrik, usahakan 
dalam waktu 3 menit sudah harus mendidih. Panaskan terus selama 10 menit (pakai stopwatch) kemudian angkat dan segera dinginkan dalam bake s. setelah dingin tambahkan $10 \mathrm{ml}$ larutan $\mathrm{Kl} 20 \%$ dan $\mathrm{H}_{2} \mathrm{SO}_{4} 25 \%$ (hati-hati terbentuk gas $\mathrm{CO}_{2}$ ). Larutan tio $0,1 \mathrm{~N}$ dengan larutan kanji $0,5 \%$ sebagai petunjuk, misal dibutuhkann $25 \mathrm{ml}$ air dan $1 \mathrm{ml}$ tio $0,1 \mathrm{~N}$. Penetapan blanko dengan $25 \mathrm{ml}$ air dan 25 larutan luff, misalnya dibutuhkan b $\mathrm{ml}$ tio 0,1 gram (SNI, 1992). Perhitungan : (b-a) $\mathrm{ml}$ tio yang dibutuhkan dijadikan $0,1000 \mathrm{~N}$ kemudian dalam daftar dicari berapa $\mathrm{mg}$ laktosa yang tertera untuk $\mathrm{ml}$ tio yang dipergunakan (W/mg).

$$
\% \text { Laktosa }=\frac{W 1 \times f p}{w} \times 100 \%
$$

Keterangan :

$$
\begin{aligned}
\mathrm{W}= & \text { Laktosa yang diperoleh dari daftar } \\
& \quad \text { dalam } \mathrm{mg} \\
\mathrm{fp} \quad= & \text { Faktor pengenceran } \\
\mathrm{W} \quad= & \text { Bobot cuplikan dalam mg. }
\end{aligned}
$$

\section{HASIL DAN PEMBAHASAN}

\section{Nilai pH}

Rataan hasil pengujian nilai $\mathrm{pH}$ pada pembuatan yogurt dengan starter dan penambahan ragi tape disajikan pada Tabel 1.

Tabel 1. Rata-rata nilai uji $\mathrm{pH}$ yogurt dengan level ragi tape yang berbeda

\begin{tabular}{cccccc}
\hline \multirow{2}{*}{ Perlakuan } & \multicolumn{4}{c}{ Ulangan } & \multirow{2}{*}{ Rata-rata \pm SD } \\
\cline { 2 - 4 } & 1 & 2 & 3 & 4 & \\
\hline P1 & 4,1 & 4,3 & 4,2 & 4,1 & $4,175 \pm 0,095$ \\
P2 & 4,4 & 4,5 & 4,5 & 4,5 & $4,475 \pm 0,050$ \\
P3 & 4,2 & 4,4 & 3,9 & 4,5 & $4,250 \pm 0,264$ \\
\hline
\end{tabular}

ns $=$ (non signifikan) tidak berbeda nyata $(\mathrm{P}>0,05)$.

Analisis ragam menunjukkan bahwa nilai rataan $\mathrm{pH}$ dengan penambahan ragi tape tidak berbeda nyata $(\mathrm{P}>0,05)$. Hasil $\mathrm{pH}$ tersebut berada dalam kisaran penelitian Roswita et al. (2007) yang melaporkan bahwa nilai $\mathrm{pH}$ yoghut tanpa penambahan ragi tape dengan kisaran 3,84,6. Penambahan ragi tape dalam pembuatan yogurt akan menghasilkan $\mathrm{pH}$ yang lebih rendah, starter biji kefir dari Saccharomyces cerevisiae dalam ragi tape mengandung jenis mikroorganisme yaitu Lactobacillus, Streptococcus, Lactococcus, Acetobacter dan khamir. Bakteri tersebut akan bersimbiosis, sehingga dapat mempercepat fermentasi dan akan menghasilkan $\mathrm{pH}$ yang lebih rendah serta kadar asam laktat yang lebih tinggi daripada kultur tunggal. Wijaningsih (2008) pH susu fermentasi dipengaruhi oleh konsentrasi starter dan lama waktu pemeraman dan bakteri asam laktat.

Saccharomyces cerevisiae yang terkandung dalam ragi tape dapat tumbuh pada $\mathrm{pH}$ 6,5. Hal ini sesuai dengan pendapat Roukas (1994) menyatakan bahwa kisaran pertumbuhan Saccharomyces cerevisiae adalah pada pH3,5-6,5 dan pada kondisi basa 
Saccharomyces cerevisiae tidak dapat tumbuh. Elevri dan Putra (2006) melaporkan bahwa produk etanol oleh Saccharomyces cerevisiae paling maksimal dapat dicapai pada $\mathrm{pH} 4,5$, dan Camacho (2003) mengatakan bahwa Saccharomyces cerevisiae tumbuh baik pada suhu $30^{\circ} \mathrm{C}$ dan $\mathrm{pH} 4,8$.

Pemberian level ragi tape yang berbeda tidak berpengaruh nyata terhadap nilai $\mathrm{pH}$ namun terjadi penurunan $\mathrm{pH}$ selama proses fermentasi selain menghasilkan etanol juga menghasilkan $\mathrm{CO}_{2}$ dan asam lainnya. Sugiarto (1991) menyatakan bahwa perubahan $\mathrm{pH}$ dalam fermentasi disebabkan karena dalam aktivitasnya sel khamir selain menghasilkan etanol sebagai metabolit primer juga menghasilkan asam-asam seperti asam malat, asam tartarat, asam sitrat, asam laktat, asam asetat, asam butirat sebagai hasil sampingan. Asamasam ini menurunkan $\mathrm{pH}$ medium.

\section{Bakteri Asam Laktat (BAL)}

Rataan hasil pengujian nilai $\mathrm{pH}$ pada pembuatan yogurt dengan starter dan penambahan ragi tape disajikan pada Tabel 2.

Tabel 2. Rata-rata nilai uji bakteri asam laktat (BAL) yogurt dengan level ragi tape yang berbeda

\begin{tabular}{cccccc}
\hline \multirow{2}{*}{ Perlakuan } & \multicolumn{4}{c}{ Ulangan } & \multirow{2}{*}{ Rata-rata \pm SD } \\
\cline { 2 - 5 } & \multicolumn{4}{c}{2} & \multicolumn{2}{c}{3} & 4 \\
\hline P1 & $27 \times 10^{8}$ & $11 \times 10^{8}$ & $21 \times 10^{8}$ & $5,6 \times 10^{8}$ & $16,15 \times 10^{8} \pm 9,6$ \\
P2 & $16 \times 10^{8}$ & $17 \times 10^{8}$ & $32 \times 10^{8}$ & $1,1 \times 10^{8}$ & $19,00 \times 10^{8} \pm 9,05$ \\
P3 & $43 \times 10^{8}$ & $15 \times 10^{8}$ & $4,6 \times 10^{8}$ & $7,4 \times 10^{8}$ & $17,5 \times 10^{8} \pm 17,5$ \\
\hline
\end{tabular}

ns $=($ non signifikan $)$, tidak berbeda nyata $(\mathrm{P}>0,05)$.

Hasil analisis ragam menunjukkan bahwa dengan penambahan ragi tape $0 \%$, $50 \%$ dan $75 \%$ tidak memberikan pengaruh nyata terhadap total bakteri asam laktat. Hasil tersebut sejalan dengan penelitian Zuhri (2014) yang melaporkan penambahan ragi tape dalam pembuatan yogurt susu kambing tidak memberikan hasil yang berbeda nyata dengan total bakteri asam laktat 7,9-8,15 $\log 10 /$ cfu. Total bakteri asam laktat dengan penambahan ragi tape tidak sesuai dengan Standar Nasional Indonesia (SNI) 2981:2009 bahwa jumlah minimal total bakteri asam laktat yang terdapat pada yogurt adalah $10^{7} \mathrm{cfu} / \mathrm{ml}$. Peningkatan jumlah bakteri asam laktat diikuti dengan dengan kadar laktosa yang tinggi. Hal ini sesuai dengan pendapat Sunarlim (2009) yang menyatakan bahwa komponen yang paling berperan selama proses fermentasi bakteri asam laktat adalah laktosa. Laktosa digunakan oleh bakteri asam laktat sebagai sumber karbon dengan hasil metabolismenya adalah asam laktat yang menyebabkan $\mathrm{pH}$ susu turun. Perubahan total bakteri asam laktat terjadi selama fermentasi. Selama proses fermentasi, laktosa diubah oleh bakteri asam laktat menjadi asam laktat. Semakin besar gula 
yang dimanfaatkan untuk menghasilkan asam laktat maka semakin besar aktivitas bakteri asam laktat. Menurut Winarno (2000), asam laktat yang dihasilkan selama proses fermentasi dapat meningkatkan citarasa dan meningkatkan keasaman atau menurunkan pHnya. Akibat terbentuknya asam laktat dan hasil metabolit bakteri asam laktat pada proses fermentasi akan berpengaruh terhadap citarasa yogurt.

Tingginya kadar bakteri asam laktat dapat disebabkan oleh beberapa faktor, diantaranya semakin bertambah lama pemeraman terdapat pertumbuhan mikroorganisme terutama bakteri asam laktat yang semakin lama menghasilkan asam laktat lebih banyak, sehingga protein yang terdenaturasi lebih banyak. Abubakar et al. (2000) menyatakan bahwa semakin lama waktu pemeraman dapat menyebabkan bakteri asam laktat menjadi semakin aktif dan menghasilkan asam laktat yang semakin banyak, hal ini dapat menyebabkan viskositas yang semakin meningkat.

\section{Laktosa}

Rataan hasil pengujian nilai $\mathrm{pH}$ pada pembuatan yogurt dengan starter dan penambahan ragi tape disajikan pada Tabel 3.

Tabel 3. Rata-rata kadar laktosa yogurt dengan level ragi tape yang berbeda

\begin{tabular}{cccccc}
\hline \multirow{2}{*}{ Perlakuan } & \multicolumn{4}{c}{ Ulangan } & \multirow{2}{*}{ Rata-rata \pm SD } \\
\cline { 2 - 4 } & 1 & 2 & 3 & 4 & \\
\hline P1 & 2,87 & 2,54 & 2,33 & 2,75 & $2,62 \pm 0,23^{\text {ns }}$ \\
P2 & 2,54 & 3,34 & 2,39 & 2,59 & $2,71 \pm 0,42^{\text {ns }}$ \\
P3 & 2,46 & 2,96 & 2,52 & 2,14 & $2,52 \pm 0,33^{\text {ns }}$ \\
\hline
\end{tabular}

$\mathrm{ns}=($ non signifikan $)$, tidak berbeda nyata $(\mathrm{P}>0,05)$. Pengukuran sampel $=\mathrm{gr} / 7,5 \mathrm{ml}$.

Rata-rata kadar laktosa pada pembuatan yogurt dengan penambahan ragi tape masing-masing $\mathrm{P} 1, \mathrm{P} 2$ dan $\mathrm{P}$, yaitu 2.62, 2.71 dan 2.52. Hasil pengujian menunjukkan bahwa pemberian starter dan penambahan ragi tape tidak memberikan pengaruh yang nyata terhadap kadar laktosa yogurt. Buckle et al. (1978) menyatakan bahwa kadar laktosa untuk semua jenis sapi perah dalam $4,8 \%$. Hal ini menunujukan bahwa terjadi penurunan kadar laktosa dari susu menjadi yogurt. Hasil tersebut sejalan dengan penelitian Tri et al. (2003) melaporkan bahwa terjadi penurunan kadar laktosa dengan penambahan kefir (Saccharomyces cerevisiae) sebanyak 16\%. Pemberian starter yang lebih tinggi pada P3 akan memperoleh kadar laktosa yang paling rendah. Hal ini disebabkan karena jumlah mikroba dalam pembuatan yogurt yang mampu mengubah laktosa susu menjadi asam laktat.

Menurut Kusmajadi et al. (1998), bahwa tingkat konsentrasi starter yang digunakan juga akan mempengaruhi kecepatan perombakan laktosa pada waktu dan suhu inkubasi yang sama. Peningkatan konsentrasi starter akan diikuti dengan peningkatan aktivitas serta perkembangbiakan. Dengan kisaran kadar laktosa 2,52-2,72 menunukkan bahwa 
kadar laktosa tersebut masih dalam kadar yang normal, dimana kadar laktosa yang normal umumnya yaitu 4,6\%. Hafsah dan Andriana (2012) melaporkan bahwa kadar laktosa yogurt tanpa penambahan ragi tape sebesar 1,94. Laktosa digunakan oleh mikroorganisme sebagai sumber karbon dan energi dengan hasil metabolismenya adalah asam laktat. Bakteri homofermentatif menghasilkan lebih dari $85 \%$ asam laktat sebagai produk metabolitnya, sehingga asam laktat yang dihasilkan mampu memberikan kondisi asam (Surono dan Inggrit, 2004).

\section{KESIMPULAN}

Berdasarkan hasil penelitian, maka dapat ditarik kesimpulan bahwa pemberian ragi tape dengan level 25\% dan 50\% tidak memberikan pengaruh terhadap sifat kimia yogurt, ditandai dengan kadar $\mathrm{pH} 3,9-4,5$, bakteri asam laktat sebesar $1,1 \times 10^{8-} 32 \mathrm{x}$ $10^{8} \mathrm{cfu} / \mathrm{ml}$ dan kadar laktosa 2,14-3,34.

\section{DAFTAR PUSTAKA}

Abubakar, E. Dyah, H. Lengkey dan D.S. Soetardjo. 2000. Kajian tentang Dosis Starter dan Lama Fermentasi Terhadap Mutu Kefir. Seminar Nasional Peternakan dan Veteriner.

Buckle, K.A., R.A. Edward, G.H. Fleet and M. Wotton. 1987, Food Science, Australia Vicc.

Camacho-Ruiz L., N. Pérez-Guerra, R.P. Roses. 2003. Factors affecting the growth of Saccharomyces cerevisiae in batch culture and in solid state fermentation. E-J Environ Agric

Food Chem 2 (5): 531-542

[DSN]. Dewan Standarisasi Nasional. 1992. Badan Standarisasi Nasional. SNI 01-2981-1992. Standar Mutu Yogurt, Jakarta

Dwidjoseputro, D. 1988. Dasar-dasar Mikrobiologi. Penerbit Djambatan. Malang.

Efryantoni. 2011. Pengaruh Konsentrasi Starter Yogurt dan Lama Inkubasi terhadap Karakteristik Set Yogurt. Skripsi Fakultas Pertanian. Universitas Bengkulu. Bengkulu

Elevri, P. A. dan S. R. Putra. 2006. Produksi etanol menggunakan Saccharomyces cerevisiae yang diamobilisasi dengan agar batang. Akta Kamindo 1. (2):105-114.

Hadiwiyoto, S., 1983. Teori dan Prosedur Pengujian Mutu Susu dan Hasil Olahannya. Liberty. Yogyakarta.

Hafsah dan Astriana. 2012. Pengaruh variasi starter terhadap kualitas yogurt susu sapi. Jurnal bionature 13 (2) : 96-102.

Kusmajadi, Suradi, Dedeh, D., Udju. D., Rusdi, dan N. Djuarnani. 1988. Pengaruh Tinggkat dan Jenis Penambahan Starter Pada Pembuatan Yogurt. Hal 191-199. dalam Prosiding Bioproses Industri Pangan. Pusat antar Universitas Pangan dan Gizi Universitas Gadjah Mada. Penerbit Liberty. Yogyakarta. 
Overby, A . J. 1988. Microbial cultures for milk processing. In : Meat Science, Milk Science and Technology. Elsiever Science Publishers B .V, New York.

Prasetyo, H. 2010. Pengaruh Penggunaan Stater Yogurt pada Level Tertentu terhadap Karakteristik Yogurt yang Dihasilkan. Skripsi Fakultas Pertanian. Universitas Sebelas Maret. Surakarta.

Roswita, S. S. Hadi., P. Masniari. 2008. Pengaruh kombinasi starter bakteri Lactobacillus bulgaricus, Streptococcus thermophilus, dan Lactobacillus plantarum terhadap sifat mutu susu fermentasi. Seminar Nasional Teknologi Peternakan dan veteriner 2007. Bogor

Roukas, T. 1994. Continuous ethanol productions from carob pod extract by immobilized Saccharomyces cerevisiae in a packed bed reactor. Journal Chem Technol Biotecnhol. 59: 387-393.

Sugiharto, P.E., 1991, Analisis Kuantitatif Kadar Etanol dari Bonggol Pisang oleh Saccharomyces cerevisiae, Skripsi Fakultas MIPA, Universitas Brawijaya, Malang

Surajudin, Kusuma, F.R., dan D., Purnomo, 2006. Yogurt, Susu Fermentasi yang Menyehatkan. Jakarta : Agromedia Pustaka. Halaman : 747.
Suriasih, K. 2011. Pengaruh Substitusi Starter Yogurt dengan cairan tape ketan terhadap karakteristik Yogurt yang dihasilkan. Skripsi Fakultas Peternakan. Universitas Udayana. Bali.

Sunarlim, R. 2009. Potensi Lactobacillus sp. Asal dadih sebagai starter pada pembuatan susu fermentasi khas Indonesia. Balai Teknologi Pascapanen Pertanian 5:69-76.

Surono dan Inggrit. 2004. Susu Fermentasi dan Kesehatan. http://www.eurekaindonesia.org. diakses 30 Desember 2014.

Susilorini, T. E. dan M. E. Sawitri, 2007. Produk Olahan Susu. Penebar Swadaya.

Tri, D. dan W. Albari. 2003. Analisa pH, Keasaman dan kadar laktosa pada yakult, yogurt, kefir. Proceeding Simposium Nasional Hasil-Hasil Penelitian di Unika Soegijapranata22 Maret 2003, ISBN: 979-8366-53-0, Semarang.

Volk, W.A. dan M.F. Wheeler. 1990. Mikrobiologi Dasar. Editor Soenartono Adisoemarto. Edisi ke5. Penerbit Erlangga. Jakarta.

Widodo, W. 2002. Bioteknologi Fermentasi Susu. Pusat Pengembangan Bioteknologi Universitas Muhammadiyah Malang. Jawa Timur.

Widodo, W. 2003. Bioteknologi Industri Susu. Lacticia Press. Yogyakarta. 
Wijaningsih, W. 2008. Aktivitas Antibakteri In Vitro dan Sifat Kimia Kefir Susu Kacang Hijau (Vigna radiata) oleh Pengaruh Jumlah Starter dan Lama Fermentasi. Tesis Program Pasca sarjana UNDIP. Semarang.

Winarno. F.G. 2000. Kimia Pangan dan Gizi. Gramedia PustakaUtama, Jakarta.
Yitnosumarto. 1993. Percobaan Perancangan Analisis Interprestasinya. PT. Gramedia.

Zuhri, A., Triana, S dan Mardidiati, S. 2014. Jumlah baktei asam laktat (BAL), Mikroba, dan kefir air susu kambing dengan konsentrasi biji kefir dan waktu fermentasi berbeda. Jurnal Ilmiah Peternakan 2(1):8793 